\title{
TMO beoordeeld: tijd voor verandering? Resultaten van het lezersonderzoek 2010
}

\author{
J.C.C. Borleffs, A.D.C. Jaarsma, namens de redactie van het TMO
}

\section{Samenvatting}

Inleiding: Het aantal artikelen dat ter publicatie aan het Tijdschrift voor Medisch Onderwijs (TMO) wordt aangeboden loopt terug. Daarom werkt de redactie van het TMO samen met het bestuur van de NVMO aan een plan voor de toekomst van het TMO. Hierbij wil de redactie de ambities van het tijdschrift versterken en de internationale uitstraling vergroten. Om de mening van TMO-lezers te peilen heeft een lezersonderzoek plaatsgevonden.

Materiaal en methoden: De vragenlijst van het lezersonderzoek is een verkorte versie van de vragenlijst die in 2003 is gebruikt met de toevoeging van enkele vragen over de Engelstaligheid. De uitnodigingen om de vragenlijst in te vullen zijn elektronisch verstuurd. De resultaten van het huidige onderzoek zijn zoveel mogelijk vergeleken met die van 2003.

Resultaten: De respons op de vragenlijst was 27\% (34\% in 2003). Het gemiddelde rapportcijfer dat de lezers het TMO geven is 7.1 waarvan $84 \%$ een 7 of hoger geeft. In 2003 was het rapportcijfer precies hetzelfde en gaf $82 \%$ een 7 of hoger. In vergelijking met 2003 is het aantal lezers dat werkzaam is in de basisopleiding iets lager (67\% versus $72 \%$ in 2003) en het aantal lezers dat werkzaam is in de medisch specialistische vervolgopleidingen hoger $44 \%$ versus $32 \%$ in 2003). $22 \%$ van de lezers heeft de laatste vijf jaar een artikel ter publicatie aan het TMO aangeboden. In 2003 was dat 27\%. Als argumenten voor het niet indienen worden tijdgebrek en de lage status van het TMO ten opzichte van Engelstalige tijdschriften genoemd. De respons op de vragen die specifiek over het Engelstalige nummer van het TMO gingen, is slecht. Ruim $25 \%$ van de respondenten heeft deze vragen niet beantwoord. Van degenen die de vragen wel beantwoord hebben heeft $27 \%$ geen mening, spreekt $31 \%$ voorkeur uit voor een Engelstalig TMO en vindt $42 \%$ dat het TMO Nederlandstalig moet blijven.

Discussie: In het algemeen is de tevredenheid over het tijdschrift ruim voldoende met een marginale stijging ten opzichte van 2003 van het aantal lezers dat een cijfer 7 of hoger geeft. In toenemende mate zijn de lezers afkomstig uit het werkdomein van de medisch specialistische vervolgopleidingen. Dit is in lijn met het beleid van de NVMO om ook een platform voor de vervolgopleidingen te worden. Het aantal lezers dat in het TMO publiceert neemt gestaag af. In 2003 had 27\% de laatste vijf jaren een manuscript ter beoordeling ingediend, nu blijkt dat percentage gedaald te zijn naar 22\%. Dit is een bevestiging van onze ervaring dat het aantal artikelen dat de redactie ter publicatie krijgt langzaam maar zeker afneemt. Een belangrijk onderdeel van de enquête waren de vragen over de Engels- of Nederlandstaligheid van het TMO. De zeer matige respons op dit onderdeel maakt dat de enige conclusie is dat 'de stemmen staken' over een voorkeur voor de voertal van het TMO.

Al met al bevestigt het huidige lezersonderzoek het beeld dat het TMO een gewaardeerd verenigingsblad is, maar voor auteurs weinig uitdagend. Dat betekent dat het tijd is voor verandering. Hiermee moet het TMO zichtbaar het verenigingsblad van de NVMO blijven, maar tevens een tijdschrift dat aantrekkelijk is voor lezers en auteurs. Internationalisering van het tijdschrift is daar een belangrijke randvoorwaarde voor. Hierbij hoort een transitie naar een Engelstalig tijdschrift. (Borleffs JCC, Jaarsma ADC. TMO beoordeeld: tijd voor 
verandering? Resultaten van het lezersonderzoek 2010. Tijdschrift voor Medisch Onderwijs 2010;29(5):276-283.)

\section{Inleiding}

Als we de geschiedenis van het Tijdschrift voor Medisch Onderwijs (TMO) bekijken heeft het tijdschrift zich sinds het eerste Bulletin Medisch Onderwijs in 1982 ontwikkeld van een gestencild bulletin tot een heus tijdschrift over onderwijs en opleiding in Nederland en Vlaanderen. De focus van het tijdschrift heeft zich in die periode verbreed van de geneeskundige basisopleiding naar andere opleidingen zoals diergeneeskunde en de medisch specialistische vervolgopleidingen. Daarnaast is het TMO ook, los van de doelstelling om een breed scala van wetenschappelijke artikelen, beschouwingen, boekbesprekingen e.d. te bieden, nadrukkelijk het verenigingsblad van de Nederlandse Vereniging voor Medisch Onderwijs (NVMO). Daarbij is de plaats die het TMO in het veld van tijdschriften op het gebied van medisch onderwijs inneemt, relatief bescheiden. Een belangrijk bestaansrecht van het TMO was altijd de aan professionals en (beginnende) wetenschappers geboden laagdrempelige mogelijkheid te publiceren in het Nederlandse taalgebied.

De ervaring leert echter dat er in toenemende mate een soort spagaat ontstaat. Enerzijds willen we nog steeds een laagdrempelig medium zijn, maar anderzijds merken we ook dat dat uitgangspunt een valkuil is. NVMO leden dragen het TMO een warm hart toe, maar hebben het TMO niet hoog op hun lijstje van tijdschriften staan waarin zij willen publiceren.

Ervan uitgaande dat we meer ambiëren dan uitsluitend een mededelingenblad van de NVMO te zijn, begint het gebrek aan internationale uitstraling ons parten te spelen. Het aantal aangeboden artikelen daalt gestaag. Slechts door jaarlijks minstens één themanummer uit te geven waarvoor auteurs worden uitgenodigd, maken we zes nummers per jaar vol. Omdat de redactie geen enkele twijfel heeft over het belang van het TMO als één van de gezichtsbepalende activiteiten van de NVMO, meent de redactie dat het tijd is de bakens te verzetten en de ambities van het TMO te versterken. De redactie heeft duidelijk voor ogen hoe dat zou moeten en voert daarover ook al een constructieve dialoog met het bestuur van de NVMO. Het eerste nummer van dit jaar dat in het Engels verscheen, en tot stand kwam in samenwerking met de redactie van het 'Zeitschrift für Medizinische Ausbildung', was een pilot om ervaring op te doen met een Engelstalig TMO. Om ook de mening van de lezers over het TMO te peilen leek ons de verschijning van dat nummer een goede aanleiding voor een nieuw lezersonderzoek.

\section{Materiaal en methoden}

De vragenlijst van het lezersonderzoek is voor een deel gebaseerd op de onderwerpen die in het lezersonderzoek van 2003 aan de orde zijn geweest. ${ }^{1}$ De lijst is echter verkort en er zijn enkele vragen over de Engelstaligheid toegevoegd. Al met al zijn de resultaten van het huidige onderzoek daarmee niet in alle opzichten vergelijkbaar met die van het onderzoek van 2003.

De uitnodigingen om de vragenlijst te beantwoorden zijn elektronisch verstuurd aan de leden van de NVMO met een (ons bekend) e-mail adres. Hoewel we ons realiseerden dat we daarmee niet alle NVMO leden en TMO abonnees zouden bereiken, bleek dat toch wel het merendeel op die manier betrokken kon worden bij het 
lezersonderzoek (>90\%). Het gemak van de elektronische verwerking van de gegevens gaf de doorslag voor deze beslissing. De planning was dat de vragenlijst circa twee weken na het verschijnen van het eerste nummer van het TMO van dit jaar zou worden verstuurd. Door een verzendprobleem bij de uitgever lag in veel gevallen het TMO helaas op de deurmat nadat de vraag voor deelname aan de enquête de lezer al had bereikt.

\section{Resultaten}

In een periode van vier weken is de vragenlijst door 266 lezers ingevuld (respons $27 \%$ ). In de tabellen worden de gegevens zoveel mogelijk vergeleken met de resultaten van 2003. Omdat op de meeste vragen meer dan één antwoord mogelijk was, is in veel gevallen het aantal antwoorden groter dan het aantal respondenten.

Tabel 1 toont een aantal karakteristieken van de respondenten. Ruim 40\% van hen is docent, $25 \%$ is medicus, $13 \%$ is opleider in de medisch specialistische vervolgopleiding en $27 \%$ is onderwijskundige. 35\% geeft aan (ook) een andere functie te hebben, zoals beleidsmedewerker, verpleegkundig specialist, ICT medewerker of met pensioen te zijn. Met uitzondering van de functies onderwijskundige en 'anders' is de verdeling van de functies van de respondenten in 2010 dezelfde als in 2003.

Wat betreft het werkdomein zien we dat het aantal respondenten uit de basisopleiding in 2010 iets is afgenomen ten opzichte van 2003 (67\% versus 72\%). In het domein medisch specialistische vervolgopleiding is het aantal respondenten relatief iets toegenomen (44\% versus 32\%). 20\% van de respondenten vulde in 2010 een 'ander' domein als werkterrein in, zoals verloskunde, biomedische wetenschappen, biomedische technologie of ziekenhuisfarmacie. In 2003 was dat $14 \%$.
Bij de vragen over de leeftijd en de nationaliteit zijn de resultaten van 2010 vergelijkbaar met die van 2003. De vraag of de lezer de laatste vijf jaar een artikel ter publicatie aan het TMO heeft aangeboden wordt in 2010 door $22 \%$ van de respondenten positief beantwoord, terwijl dat in 2003 27\% was. Als argumenten voor het niet indienen worden tijdgebrek en de lage status van het TMO ten opzichte van Engelstalige tijdschriften het meest genoemd.

Tabel 2 presenteert enkele kenmerken van het lezersgedrag van de respondenten. Ruim $40 \%$ leest het TMO altijd of vaak, $30 \%$ regelmatig en $30 \%$ soms tot nooit. Het gemiddelde rapportcijfer dat de lezers het TMO geven is 7.1 waarvan $84 \%$ een 7 of hoger geeft. In 2003 was het rapportcijfer precies hetzelfde en gaf $82 \%$ een 7 of hoger.

In Tabel 3 wordt de voorkeur van de respondenten voor de rubrieken van het TMO weergegeven. Door verschillen in de rubrieken in 2010 en 2003 zijn de enquêteresultaten niet volledig vergelijkbaar. De belangstelling voor het Redactioneel en voor de beschouwende artikelen is in 2010 aanzienlijk groter dan in 2003 (respectievelijk $51 \%$ versus $23 \%$ en $72 \%$ versus 59\%). In 2003 waren 'andere' rubrieken redelijk populair. Dit betrof vooral Ingezonden brieven en Bestuursmededelingen. De rubriek Onderwijs in de praktijk scoorde in het onderzoek van 2003 hoog. In de afgelopen jaren is deze rubriek echter opgedroogd.

Tabel 4 laat zien over welke onderwerpen de respondenten graag willen lezen in het TMO. Ontwikkelingen in de UMC's, de basisopleiding geneeskunde en de medisch specialistische vervolgopleidingen scoren hoog, zelfs aanzienlijk hoger dan in 2003. De hoge score voor het onderwerp 'anders' werd in 2003 gedomineerd door 'vertaalde topartikelen over medisch onderwijs in 
buitenlandse tijdschriften'. In 2010 was dat nauwelijks een voorkeursonderwerp.

\section{Nederlands- of Engelstalig TMO}

De respons op de vragen die specifiek over het Engelstalige nummer van het TMO gingen, is helaas matig. Ruim $25 \%$ van de respondenten heeft deze vragen niet beantwoord. Het rapportcijfer dat de respondenten gaven voor het Engelstalige nummer was 7.0 waarvan $79 \%$ een 7 of hoger gaf. Onder de respondenten vindt $42 \%$ dat het TMO Nederlandstalig moet blijven, spreekt $31 \%$ voorkeur uit voor een Engelstalig TMO en heeft 27\% geen mening. De slechte respons maakt dat de betrouwbaarheid van deze gegevens beperkt is.

De door de respondenten beschreven argumenten vóór Engelstaligheid zijn de vergroting van de mogelijkheden voor internationale samenwerking en het inter-

Tabel 1. Lezersprofiel (bij de meeste vragen zijn meerdere antwoorden mogelijk).

\begin{tabular}{|c|c|c|c|}
\hline & & $\begin{array}{c}\text { Onderzoek } \\
2010(\%)\end{array}$ & $\begin{array}{c}\text { Onderzoek } \\
2003(\%)\end{array}$ \\
\hline & Respons (n) & $\begin{array}{l}27 \\
(266)\end{array}$ & $\begin{array}{c}34 \\
(254)\end{array}$ \\
\hline \multirow[t]{7}{*}{ Functie } & Docent & 42.6 & 46.5 \\
\hline & Arts & 23.6 & 24.0 \\
\hline & Aios & 1.5 & 0.7 \\
\hline & Student & 2.3 & 2.0 \\
\hline & Opleider & 13.3 & 13.0 \\
\hline & Onderwijskundige & 27.4 & 16.1 \\
\hline & Anders & 35.0 & 45.3 \\
\hline \multirow[t]{5}{*}{ Werkdomein } & Basisopleiding geneeskunde & 67.7 & 72.4 \\
\hline & Medisch specialistische vervolgopleiding & 44.2 & 32.3 \\
\hline & Opleiding diergeneeskunde & 1.9 & 5.7 \\
\hline & Opleiding tandheelkunde & 6.9 & - \\
\hline & Anders & 20.4 & 14.6 \\
\hline \multirow[t]{5}{*}{ Leeftijd } & $20-30$ & 11.4 & 8.3 \\
\hline & $31-40$ & 18.7 & 13.0 \\
\hline & $41-50$ & 25.6 & 28.7 \\
\hline & $51-60$ & 32.2 & 40.6 \\
\hline & $>60$ & 11.9 & 9.4 \\
\hline \multirow[t]{3}{*}{ Werkzaam in } & Nederland & 94.6 & 97.6 \\
\hline & Vlaanderen & 4.6 & 2.0 \\
\hline & Elders & 1.1 & 0.4 \\
\hline Laatste vijf jaar manuscript & $\mathrm{Ja}$ & 22.6 & 27.4 \\
\hline $\begin{array}{l}\text { ter publicatie aan het TMO } \\
\text { aangeboden }\end{array}$ & Nee & 77.4 & 72.6 \\
\hline
\end{tabular}


nationale aanzien van het Nederlands medisch onderwijs, de mogelijkheid van indexering van het TMO in internationale bibliotheken en databases, het aanboren van een breder lezers- en auteurspubliek en een grotere aantrekkelijkheid voor promovendi.

Tegenargumenten zijn dat het TMO een Nederlandse spreekbuis van de NVMO moet blijven, Engels de leesbaarheid vermindert en de drempel voor het indienen van een manuscript te veel verhoogt en dat er al (te) veel Engelstalige tijdschriften op dit terrein bestaan.
Tabel 2. Leesgedrag.

\begin{tabular}{lc}
\hline Hoe vaak leest $\mathbf{u}$ het TMO? & $\%$ \\
\hline Altijd & 21.0 \\
Vaak & 19.3 \\
Regelmatig & 30.3 \\
Soms & 28.2 \\
Nooit & 1.3 \\
\hline
\end{tabular}

Tabel 3. Voorkeur voor rubrieken van het TMO (meerdere antwoorden mogelijk).

\begin{tabular}{lcc}
\hline Rubriek & Onderzoek 2010 (\%) & Onderzoek 2003 (\%) \\
\hline Redactioneel & 51.8 & 23.2 \\
Onderzoek & 77.8 & 72.4 \\
Beschouwende/opiniërende artikelen & 72.4 & 59.8 \\
Cultuur en gezondheidszorg & 19.8 & - \\
Pro/contra & 45.9 & - \\
Promovendi & 30.0 & - \\
Boekbesprekingen & 34.2 & 37.4 \\
Referaten & 15.2 & 11.4 \\
Congresverslagen & 17.5 & 16.5 \\
Onderwijs in de praktijk & - & 74.0 \\
Anders & 3.1 & 27.5 \\
\hline
\end{tabular}

Tabel 4. Voorkeursonderwerpen van lezers (meerdere antwoorden mogelijk).

\begin{tabular}{lcc}
\hline Onderwerp & Onderzoek 2010 (\%) & Onderzoek 2003 (\%) \\
\hline Actuele ontwikkelingen in UMC's en & 73.8 & 52.3 \\
$\quad$ andere faculteiten & 64.5 & 43.7 \\
Basisopleiding geneeskunde & 54.7 & 39.4 \\
Medisch specialistische vervolgopleidingen & 12.5 & 9.8 \\
Andere (niet geneeskundige) opleidingen & 26.6 & 37.0 \\
Beleid overheid & 11.7 & 58.3 \\
Anders & & \\
\hline
\end{tabular}




\section{Discussie}

Het lezersonderzoek levert een aantal interessante bevindingen op. Beoordeeld op basis van het rapportcijfer is in het algemeen de tevredenheid over het tijdschrift ruim voldoende met een marginale stijging ten opzichte van 2003 van het aantal lezers dat een cijfer 7 of hoger geeft. Vergelijking van de lezerskarakteristieken van het onderzoek van 2003 met die van 2010 laat een sterke toename zien van lezers uit het werkdomein van de medisch specialistische vervolgopleidingen. Dit is verheugend omdat een belangrijk beleidspunt van de NVMO is om ook een platform voor de vervolgopleidingen te worden.

Wat betreft de inhoud van het TMO is de sterk toegenomen belangstelling voor het Redactioneel een opmerkelijke en in het bijzonder voor de redactie zeer positieve bevinding! De rubriek Onderwijs in de praktijk mocht zich in 2003 verheugen in een grote populariteit. Het is jammer dat het aanbod van artikelen voor deze rubriek de afgelopen jaren stagneert.

Maar het onderzoek levert ook een aantal bevindingen op dat aanleiding geeft tot reflectie. Iets meer van $70 \%$ van de lezers leest het TMO regelmatig, vaak of altijd. Dat is natuurlijk heel verheugend. Maar bijna 30\% leest het tijdschrift soms of zelfs nooit. Helaas hebben we deze vraag in 2003 niet zo expliciet gesteld. Daardoor kunnen we niet beoordelen hoe het leesgedrag zich de laatste jaren heeft ontwikkeld. Omdat er met uitzondering van de vragen over de Engelstaligheid slechts weinig vragen in het lezersonderzoek onbeantwoord bleven, zijn vraagtekens te zetten bij de betrouwbaarheid van het recente onderzoek. Veel respondenten hebben kennelijk een mening over het TMO terwijl zij het tijdschrift niet of nauwelijks lezen.

Het aantal lezers dat in het TMO publiceert neemt gestaag af. In 2003 had
$27 \%$ de laatste vijf jaren een manuscript ter beoordeling ingediend, nu blijkt dat percentage inmiddels gedaald te zijn naar $22 \%$. Dit is een bevestiging van onze ervaring dat het aantal artikelen dat de redactie ter publicatie krijgt langzaam maar zeker afneemt.

De vragen over de Engels- of Nederlandstaligheid van het TMO vormden een belangrijk onderdeel van de enquête. Met ruim $25 \%$ van de lezers die dit onderdeel van de enquête niet heeft ingevuld, is de interpretatie van dit deel van de vragenlijst helaas onbetrouwbaar. Wellicht zijn de grote problemen bij de verzending van het Engelstalige nummer van het TMO daar de oorzaak van. Hierdoor kreeg een deel van de lezers eerst de vragenlijst toegestuurd en pas daarna het TMO. Het is dan ook zeer de vraag hoeveel waarde we moeten hechten aan de samenvattende resultaten. Al met al kunnen we weinig anders concluderen dan dat op grond van de vragenlijst 'de stemmen staken' over een voorkeur voor de voertaal van het TMO.

De individuele opmerkingen zijn echter wel interessant. De genoemde argumenten vóór Engelstaligheid sluiten aan bij de visie van de redactie over de toekomst van het TMO. De tegenargumenten zijn een belangrijk signaal, waar we zo veel mogelijk rekening mee moeten houden bij de plannen om het TMO om te buigen naar een Engelstalig tijdschrift. Dat betekent dat het uitgangspunt moet blijven dat het TMO het verenigingsblad van de NVMO is. Handhaving van enkele voor het TMO kenmerkende rubrieken moet bijdragen aan die herkenbaarheid. Voor bestuursmededelingen en andere rubrieken die alleen voor Nederlandse en Vlaamse lezers relevant zijn, zou bijvoorbeeld een Nederlandstalig katern of speciaal gedeelte kunnen worden gebruikt. Er zijn in Nederland vele voorbeelden van verenigingstijdschriften die zeer succesvol een transitie naar 
het Engels hebben doorgemaakt. Met een Engelstalig TMO wordt niet alleen een Nederlands maar ook een internationaal lezerspubliek bereikt. De omvang van medisch onderwijskundige ontwikkelingen in en buiten Europa en het wetenschappelijk onderzoek op dat terrein rechtvaardigen het bestaansrecht van een nieuw (internationaal) Europees tijdschrift.

\section{Hoe nu verder?}

Het TMO heeft zich in haar bijna 30-jarig bestaan ontwikkeld tot een belangrijk visitekaartje van de NVMO. Het huidige format van het TMO maakt dat verdere groei en kwaliteitsverbetering niet erg voor de hand liggen. Het huidige lezersonderzoek bevestigt, met alle mitsen en maren die je bij de betrouwbaarheid van de resultaten mag zetten, het beeld dat het een gewaardeerd verenigingsblad is, maar voor auteurs weinig uitdagend. En dat moet anders en beter kunnen. Zeker voor een visitekaartje dat in termen van kosten voor de NVMO de grootste uitgavenpost is. Het bestuur van de NVMO heeft inmiddels het voorstel van de redactie om van het TMO een Engelstalig tijdschrift te maken ondersteund. Daarbij heeft het bestuur de redactie gevraagd een plan voor deze transitie nader uit te werken. In de najaarsvergadering tijdens het NVMO Congres in Egmond aan Zee zal dit plan worden toegelicht. Ervan uitgaande dat de definitieve besluitvorming hierover positief zal zijn, zal precies 30 jaar na het eerste Bulletin Medisch Onderwijs in 2012 the Netherlands Journal of Medical Education voor het eerst verschijnen.

\section{Dankbetuiging}

De redactie bedankt drs. T.B.B. (Tobias) Boerboom van de faculteit Diergeneeskunde van de Universiteit Utrecht voor zijn hulp bij de verzending van de vragenlijst en de verzameling van de gegevens.

\section{Literatuur}

1. Borleffs JCC. TMO beoordeeld: resultaten van het lezersonderzoek 2003. Tijdschrift voor Medisch Onderwijs 2004;23(3):153-160. [An evaluation of the Netherlands Jounal of Medical Education: results of a readership survey in 2003. Netherlands Journal of Medical Education 2004;23(3):153$160]$.

De auteurs:

Prof. dr. J.C.C. Borleffs is vice-decaan onderwijs en opleiding van het UMC Groningen. Voorts is hij hoofdredacteur van het Tijdschrift voor Medisch Onderwijs. Mw. dr. A.D.C. Jaarsma is universitair docent bij de leerstoel Kwaliteitsbevordering Diergeneeskundig Onderwijs van de faculteit Diergeneeskunde, Universiteit Utrecht. Voorts is zij lid van de redactie van het Tijdschrift voor Medisch Onderwijs.

Correspondentieadres:

Prof. dr. J.C.C. Borleffs, UMCG, A. Deusinglaan 1, 9713 AV Groningen.E-mail: j.c.c.borleffs@med.umcg.nl

Belangenconflict: geen gemeld

Financiële ondersteuning: geen gemeld 


\section{Summary}

Introduction: The number of manuscripts submitted to the Netherlands Journal of Medical Education (TMO) is decreasing. Consequently, the editorial board of the journal has reflected on what type of measures might be taken to change this trend. The ambitions of the journal need to be strengthened and its international profile become more prominent. A survey was conducted to explore readers' thoughts on this matter.

Materials and methods: The content of questionnaire was based on the 2003 survey with questions added about the preferred language of the journal. Readers were invited by email to complete the questionnaire. We compared the results of this survey with those of the 2003 survey.

Results: The response rate was $27 \%$ (34\% in 2003). The mean appreciation of the journal was 7.1 (scale from 1-10), with $84 \%$ of the readers giving a rating $\geq 7$. In 2003 the mean score was exactly the same, with $82 \%$ of the readers rating their appreciation $\geq 7$. Compared to 2003 the number of readers working in the area of undergraduate training had decreased from $72 \%$ to $67 \%$, whereas the number of readers active in postgraduate medical specialist training had increased from $32 \%$ to $44 \%$. During the last five years $22 \%$ of the readers had submitted a manuscript to TMO compared to $27 \%$ in 2003. Reasons for non-submission given by respondents that had never submitted a paper included lack of time and TMO's low international status. Unfortunately, the response to our questions about the language of the journal was limited. Among the responders, 27\% had no opinion, 31\% preferred English and $42 \%$ preferred Dutch as the journal's language.

Discussion: In general, readers' satisfaction with the journal is stable and satisfactory, with a slight increase in the number of readers scoring $\geq 7$ compared to the 2003 survey. The marked increase in the number of readers active in postgraduate training is probably due to the policy of the Netherlands Association for Medical Education (NVMO) to become a platform for discussion in this field. The number of readers submitting manuscripts to TMO is gradually decreasing. This confirms the editorial board's observation that authors' interest in TMO is declining. Considering the low response to the questions dealing with the preferred language of TMO, the only conclusion that can be justified seems to be that the votes for English and Dutch are more or less equal.

In summary, the survey confirms that readers appreciate TMO as the NVMO's club journal, but that the journal doesn't offer enough challenges for readers and authors. Consequently, it is time for change to make the journal more attractive. An international profile with a transition to an English-language journal can be an important condition for this. (Borleffs JCC, Jaarsma ADC on behalf of the editorial board. An evaluation of the Netherlands Journal of Medical Education: time for a change? Netherlands Journal of Medical Education 2010;29(5):276-283.) 